\title{
On the Internationalization of Higher Education Institutions in China
}

\author{
Jun Liu \\ College of Foreign Languages, North China Electric Power University \\ No 2, Beinong Road, Huilongguan, Changping District, Beijing 102206, China \\ E-mail: liuj59@126.com \\ Zhongxin Dai \\ College of Foreign Languages, North China Electric Power University \\ No 2, Beinong Road, Huilongguan, Changping District, Beijing 102206, China \\ E-mail: zhongxindai@126.com
}

Received: January 10, 2012 Accepted: January 18, 2012 Published: March 1, 2012

doi:10.5539/hes.v2n1p60

URL: http://dx.doi.org/10.5539/hes.v2n1p60

\begin{abstract}
This paper discusses issues concerning the internalization of higher education institutions in China. Internationalization of a university involves the internationalization of the curriculum, the administration and management, collaborative academic research, and exchange of students and staff.
\end{abstract}

Keywords: Internationalization, Higher education, Institution, China

\section{Introduction}

The past three decades has witnessed significant progress in the higher education system in China in response to the burgeoning economy and favorable policies from the government. As the carrier, bearer or vehicle of higher education, institutions (the body of which consists of universities and colleges) have undergone expansion, merging and internationalization. The issue of internationalization of higher education has generated a huge amount of literature, but precisely how a university undergoes internalization, and how teachers and students experience internalization and eventually become internationalized are issues infrequently addressed.

The suffix "-ize" in the word "internationalize" is a word ending which describes a process by which things or people are brought into a new state of the quality of the adjective. Therefore, to "internationalize" a university is to make it become "international". The "internationalization" of a university refers to the process by which the university is made to assume the characteristics or features of being international. A university, as a knowledge-producing entity, consists of administrative organizations, staff members, students, facilities and resources, buildings, etc. It also has its own history, culture, and operating system. It has tripartite mission: teaching, research and service (Maringe \& Foskett, 2010). If we compare the entity of a university to a machine, the machine as a whole would first be internationalized, and then the product (i.e. the students) would assume the international quality. It is easier to talk generally about the internationalization of a university, but when it comes to the detailed concrete step-by-step process, it is quite likely that we become bewildered as to how to approach the issue of internationalization of a university. In this paper, we intend to address three concrete issues: the internationalization of curricula and teaching, of management, and of communication, in the hope of depicting an overall picture of the internationalization process of a university.

\section{Internationalization of Curricula}

The word "curriculum", stemming from the Latin word for race course, refers to a systematic set of courses, including their content, taught by teachers. In a university, the entire university curriculum is composed of a hierarchical system of courses with some being basic or fundamental for some specialties, and some being more specific and practical. The central task of a university is the designing and implementation of its curriculum. The curriculum is regarded as the course in which students experience what they are supposed to experience and grow with the experience. The value of the existence of a university is that it provides a curriculum that satisfies the need of the society or community and the needs of people pursuing post-secondary education and development. In a sense, the internationalization of a university is the internationalization of its curriculum, and hence the internationalization 


\section{of students' experience.}

According to Dewey (1963), the quality of education is based upon the quality of experience. Dewey's ideas hinge on the relationship between education and experience. There are two principles of experience: continuity and interaction, which are the longitude and latitude of experience. Learning is on-going. Every experience changes the individual and potentially opens the doors for more learning. From this point of view, the principle of continuity of experience means that every experience both takes up something from those which have gone before and modifies in some way the quality of those which come after. Experience is a moving force. Its value can be judged only on the ground of what it moves towards and into. Therefore, experiences can be categorized as possibly being educative, mis-educative or simply non-educative. An educative experience is one that contributes positively to the student's growth in the direction where the student is expected to move. A mis-educative experience is one that stops or distorts the student's growth for future experiences. A non-educative experience is one in which a person has not done any reflection and so has obtained nothing for mental growth. "Interaction" expresses the educational function and force. It refers to both the objective and the internal conditions. Any normal experience is an interplay of these two sets of conditions. Taken together, or in their interaction, they form what we call a situation (Dewey, p.42).

Jane Knight (1993, 2003, 2004) defines internationalization as the process of integrating an international, intercultural, or global dimension into the purpose, functions or delivery of post secondary education. We extend this definition into the internationalization of the curriculum. The internationalization of the curriculum of a university is to integrate the international, intercultural or global dimension into the teaching and learning activities of the university. We draw upon Dewey's conception of "continuity" and "interaction" in the discussion of the internationalization of curriculum in a university. If we believe in the conception that the student's experience leads to his growth, it goes without saying that we want our students to have experience with international and intercultural interactions or situations. The next thing we are to consider is what constitutes the daily situation where students gain their experience. Students interact with instructors and administrative staff members, course-books and other resources, experimental equipment and instruments, learning facilities, manners of instruction and administrative management, rules or regulations, and many other numerous things. If they communicate with people with international or intercultural qualities or traits, they themselves may learn how to behave in communication and reflect on the differences between intra-cultural and intercultural communications. If they experience a course offered by a foreigner, then it is quite natural that they experience not only the content of the subject matter of the course, but the instructor's approach to the teaching content, his manner of behavior, his beliefs, his worldview, and his attitudes towards the teaching profession, towards research, towards life, towards society, and towards the students. This perspective on the internationalization of curriculum puts us in a position to view the issue from the following aspects.

\section{(1) Instructors with international and intercultural background}

Internationalization of the curriculum in a university cannot be rendered possible without internationalization of the instructors. Most of the student's experience is composed of interaction with his instructors. The interaction experience with the instructors contributes greatly to the student's academic and intellectual growth. The instructors' knowledge of the subject matter of the courses, their earnest pursuit of scientific truth, hard work and perseverance, attitudes towards life and the world, work or professional ethic, and even their love and interest, all affect their students via interaction with them in and outside class. Instructors with international and intercultural background know very well what their students need in order to make them "internationalized" as the instructors themselves have undergone the experience of internationalization.

There are implicit and explicit approaches to the exercising of influence on students. Implicit influence is through how instructors behave rather than what they tell their students explicitly. For instance, in China, students are supposed to erase the blackboard for their instructors. An instructor with international and intercultural background may erase the board himself immediately after he finishes his instruction no matter whether he will use the board in the next session. If a student offers to clean the board, the instructor would thank the student for doing so. (In traditional teaching situations, teachers never thank their students for erasing the board.) Students present in the class experience what the instructor does or says to the student and notice the difference between his behavior and the behavior of other instructors. Their awareness of the difference will suffice for them to appreciate the manner of the instructor and think about the underlying ideology. If the instructor explicitly informs his students of the underlying ideology of his behavior, then the influence on the students is an explicit one. Another example: an instructor may assign students to accomplish a project in a group with each playing a different part in the project. The students will finish the project and develop the ability to work in a team. The development and growth of the students are unconscious and implicit. But if the instructor explains to the students why they do not have test papers as they formerly do, the students will be consciously aware of the instructor's intention and attempt to develop the 
ability to do team work. Internationalization of class activities and management entails the internationalization of instructors.

(2) Courses analogous to those of comparable universities in the West

The university curriculum contains a set of courses, more exactly a hierarchical set of courses. A university has different colleges, which is further divided in China into departments. Courses or course modules are grouped to meet the requirements of different majors. The grouping of courses or course modules is held responsible for the specifications of the graduates. In this sense we say that the quality of the graduates can be well judged by the courses the university offers to them. If universities in China want to catch up with universities in developed countries, they should first of all design and develop their courses analogous to the courses in those universities. The internationalization of courses involves judgment of the advance and relevance of knowledge, i.e. what knowledge area should be included, the arrangement of the courses, the approaches to the implementation of the courses, etc.

(3) A foreign language as a working language

Language is a tool for communication. If students are expected to communicate with foreigners upon their graduation, it is advisable to use the language of the foreigners in class. English is regarded as an international language, and therefore in most cases English is used in bilingual courses in China. The English language requirement demands instructors with high English proficiency. Those who cannot conduct their instruction in English may use English course-books and give lectures in Chinese; those with high English proficiency may select English materials for their lectures or choose course-books in English and add supplementary materials in English. In order to internationalize students, the content of the subject matter of the courses opened to them should be verbalized in the language in which they will communicate in the future with foreign researchers working in the fields of the subject matter. This is an important part in the internationalization of students. When we speak of the internationalization of students, we do not mean that every part of the students, physical or spiritual, can be converted into something international. We simply indicate that they can use English to share with foreigners their ideas, feelings, beliefs, value judgment, etc. in an across-cultural manner.

Reasonable proficiency in English is a prerequisite for the courses offered in English. Only with this prerequisite can bilingual courses or courses in English be offered, foreign teachers employed, foreign students accepted on a large scale, and cooperative education programs made possible. In this sense, College English (a special term in China to refer to English taught to non-English majors) teaching in China is not just part of the quality-oriented education, but it is held responsible for the important task of the internationalization of the university. The English proficiency of the teachers and students of a university indicates the degree and potential possibility of the internalization of the university. Internationalized prestigious universities can form dialogues with international counterparts in English on all levels. Therefore, it is no surprising to find that English courses for general and specific purposes are placed in an important position in most developing countries all over the world.

\section{Internationalization of University Management}

University management has its own internal and external operating mechanisms. Follow the mechanisms of operation, and a university will prosper and flourish; otherwise, it will stop developing or move in a wrong direction. For many years in the past, universities in China were run on experience, and under the planning system and "red-tape" administration. Since the 1980s, higher education system has significantly changed, but the change of higher education system does not mean the change of ideology, or the raising of the level of scientific management. Time is needed for the change of ideology and improvement of management. It is high time that university administrators investigated the development and management of higher education and the demands of contemporary society and economy on higher education. When they have learned to employ the theories of marketing and value relations, they will be in a position to "sell" their universities in the national and international markets of higher education, and the university will have its place among competitive universities.

China has become a member of the World Trade Organization. "Education", as an industry, has been included in the General Agreement on Trade in Services, and thus China has become part of the world's education market. Higher education in China has been involved in higher education in the world market. In this context, universities in China are facing enormous challenges, but embracing a lot of potential opportunities for development as well. As an independent legal entity, a university should change its ideology, conduct self-management, participate in the competition, and seek its own proper way for development. These are crucial factors that impede the internationalization of universities. As universities in China have just started internationalization, and still have drawbacks of the planning system, international exchanges and dialogues have not been initiated at all levels of universities. The managers or administrators of a university are supposed to make policies to encourage and stimulate internationalization, make significant breakthroughs and initiate launch programs. 
With higher education in China opening up to the world, institutions of higher education have become a promising international market for other institutions of higher education in the world. Meanwhile, the internationalization of higher education in China has become increasingly intensified. The management of a university has to face an open environment both national and international. All universities in China compete in the international market and compete among themselves in the national market. The open and competitive environment requires universities in China to make corresponding policies. Open and competitive management means free competition and flow at all levels of a university. Universities compete with other universities domestic and abroad, and different levels inside a university compete with each other. An open and competitive education market resembles an open and competitive economic market, requiring managers to use the model of economic management in the management of higher education.

Since the 1980s, higher education institutions have become real entities of their own business, and the role of the government is to guide and supervise by way of making policies and legislation. The open environment and the role of self-management require university managers and administrators to update their notion of international and market-oriented education, equip themselves with keen insights and make full use of and take advantage of the resources available. The quality of the administrators and managers of higher education institutions guarantees the quality of their internationalization.

\section{Collaboration with Institutions Abroad}

Frequent exchanges and collaboration with foreign universities feature in the internationalization of higher education institutions. A large proportion of the school routine work is dealing with internationalization affairs. In other words, international businesses have become part of daily routine, and relevant news is no longer shocking news. As internationalization occurs at all levels of the university, exchange and collaboration also occur at all levels. Three areas of exchange and cooperation are identified: academic research, collaborative education and exchange of teachers and students. Exchange and collaboration in the area of academic research are an important aspect of the internationalization of a university. A university expands its cross-border research on the bases of its academic tradition, conditions and advantages. Multinational research can take many forms. It can be short academic conferences or seminars, or collaborative research projects in the research field. Collaborative education also takes many forms, and is sometimes used as an umbrella term covering both academic research and cooperation programs of exchanges of staff and students. This can be illustrated in the list of current cooperative programs of Jiangsu University (Note 1).

1) Wilfrid Laurier University (Canada) “2+2” Photoelectricity Inter-university Exchange Program

2) Jiangsu-Ontario University Student Exchange Program

3) Work \& Travel USA Program

4) Jiangsu University \& Houston University “ $3+1$ ” Student Exchange Program

5) University of California at Berkeley Short-term Academic Visit Program

6) University of California at San Diego Short-term Academic Visit Program

7) Jiangsu University \& Yeungnam University (Korea) Inter-university Student Exchange Program

8) Jiangsu University \& Chienkuo Technology University (Taiwan) Student Exchange Cooperative Program

9) Professional Field Work in Chemnitz (Germany)

10) Jiangsu University \& Leeds University (UK) Food Science and Engineering Undergraduate Cooperative Education Program (international courses pilot class)

11) Jiangsu University \& Arcadia University (USA) Mathematics and Applied Mathematics Undergraduate Cooperative Education Program (international courses pilot class)

We can see from the above list what an average university is currently doing in terms of cooperative educational programs. It should be pointed out that against the large population of the university, the number of staff members and students involved in the current programs is remarkably small.

\section{Conclusion}

The value of internationalization of higher education institutions has been recognized by all universities in China, which can be justified by the vision statement and strategic plans of the universities. However, the recognition of the value of the internationalization is one thing, and the implementation of the strategic plans or the realization of the visions is another. Challenges still remain in the coherence and integration of internationalization within a university with respect to the internationalization of the curriculum and teaching, administration and management, exchange of 
students and staff, and collaborative academic research. Universities in China have accumulated a wealth of innovative ideas. Each university needs to understand its own tradition and culture, and to carefully assess what it has done, what it can do and what will work well. It is hoped that through the experience of the practices it has undergone, through integration of all the current good practices, and through the endeavor that it will make to implement its strategic plan of internationalization, each university will eventually establish its overall supportive policy frameworks to encourage and stimulate internationalization at all levels.

\section{References}

Dewey, J. (1963). Experience and education. New York: Collier Books.

Knight, J (1993). Internationalization: management strategies and issues. International Education Magazine. 9, 6, $21-22$.

Knight, J. (2003). Updated internationalization definition, International Higher Education. 33, 2-3.

Knight, J. (2004). Internationalization remodeled: Definition, approaches, and rationales. Journal of Studies in International Education. 8, 5-31. http://dx.doi.org/10.1177/1028315303260832

Maringe, F. \& Foskett, N. (2010). Introduction: Globalization and universities. In F. Maringe \& N. Foskett. Globalization and internationalization in higher education: theoretical, strategic and management perspectives (pp.

1-16). London/New York: Continuum International Publishing Group.

Notes

Note 1. http://eng.ujs.edu.cn/cooperation/cooperation-program 